\title{
Main Directions Digitalization in the Higher Education in the World and Russia (Based on the Example of Physical Culture and Sports)
}

\author{
Victor L. Kondakov ${ }^{*}$, Evgeniya N. Kopeikina, Irina G. Voloshina, Alexander N. Usatov \\ Belgorod State University, Russia
}

Received July 22, 2019; Revised September 21, 2019; Accepted September 30, 2019

Copyright $(2019$ by authors, all rights reserved. Authors agree that this article remains permanently open access under the terms of the Creative Commons Attribution License 4.0 International License

\begin{abstract}
Objectives: On the basis of the analysis of scientific research, we have made an attempt to determine the main directions of the development of digitalization in the system of higher education in the field of physical culture and sports in Russia for the next decade. Materials and Methods: The material for this article is the result of our own research and an analytical review of scientific works of domestic and foreign scientists in recent years. Results: The obtained results can be considered a significant proof of the relevance of this area of research. The analysis shows the need to master modern information technologies in the field of higher education. This requires the development and implementation in the educational process of higher education of professionally oriented program and program and pedagogical tools aimed at mastering the necessary knowledge, as well as accumulating personal experience in their use in pedagogical and sports activities. Conclusion: In our opinion, four main areas of use of modern digitalization in physical culture and sports can be distinguished: in the educational process; in the process of sports training; in the process of competition; in health improving physical culture.
\end{abstract}

Keywords Digitization, IT Penetration, Higher Education, Physical Culture, Smart, Sport

\section{Introduction}

All spheres of human life including education have been touched by major changes today. A huge role in these transformations belongs to the rapid development of scientific and technological progress, global digitalization of the advanced countries of the world community, information technologies (IT) penetration into all spheres of our life.

Summarizing the opinions of domestic and foreign scientists we can state that the education system does not meet modern requirements and, as a result, undergoes the state of crisis [ Mohorovičić, et al. 2011- David \& Abreu, 2014; Amiri Mikal, et al 2016].

The world today is on the verge of a new wave of innovation that can seriously change the educational landscape and therefore new directions in the system of higher education should be taken into account by universities interested in their development. Three main trends can be distinguished:

- internationalization or globalization of higher education;

- digitization of education - the transformation of information into a digital form. More technological definition: digital transmission of data encoded in discrete signal pulses;

- the change of sources of financing in the current conditions of the world economy, the formation of an innovative technological order in industry.

Let's consider in more detail the second trend which is digitalization of education, caused by the digital revolution in the world and related to the rapid development of modern information and communication technologies. In January 2018, the number of Internet users in the world reached 4,021 billion people (the entire population of the planet is 7.6 billion), most of them are young and working people interested in obtaining or improving their professional qualifications. Annual growth is 7\%. Internet is distributed unevenly around the world. The highest internalization is observed in Northern Europe (94\%), Western Europe (90\%) and North America (88\%). In percentage terms, the largest penetration of the Internet remains in developed countries - $81 \%$, compared with $40 \%$ in developing countries and $15 \%$ in the least developed 
countries. ("Global Digital 2018" from We Are Social and Hoot suite). Therefore, new technological innovations open for digitalization the higher education system unprecedented opportunities to increase the effectiveness of existing educational programs and contribute to the emergence of new market niches for educational experiments that are developing simultaneously with the traditional education system that has developed in recent centuries. To determine the main directions of development of information technologies in the system of higher education in the field of physical culture and sports in Russia for the next decade.

\section{Materials and Methods}

The material for this article is the results of our own research and an analytical review of scientific works of domestic and foreign scientists in recent years. We have analyzed over 40 papers on this subject, including those indexed in the SCOPUS and Web of Science database (Table. 1). Those works considered the following items digitalization in the education:
- introduction of innovations in IT-sphere of higher education;

- use of information and communication technologies in the educational process in universities;

- $\quad$ education management systems;

- risks when introducing new electronic control systems in universities;

- application of information technology in teaching various disciplines.

Information technology is a mixture of devices, methods and tools that allow to operate information outside the human brain. These are computers and software, peripherals and communication systems. Recently, the process of formation of the information society taking place in Russia, poses the task of digitalization of the education system [ Izmalkova, et al. 2014, Gushchin, 2015Bastian, 2017; Cuevas, et al 2018].

One of the main tools of digitalization of society is ITs. They allow a radical change in the vital activity of each person. The development of a strategy for the development and use of IT in all spheres of human activity is one of the key problems of strategic planning both at the state and world level. 
Table 1. Main directions digitalization in the higher education

\begin{tabular}{|c|c|c|c|c|c|}
\hline \multirow[b]{2}{*}{ Author(s) } & \multicolumn{5}{|c|}{ Direction of research } \\
\hline & $\begin{array}{l}\text { use of information and } \\
\text { communication } \\
\text { technologies in the } \\
\text { educational process in } \\
\text { universities }\end{array}$ & $\begin{array}{l}\text { education } \\
\text { management } \\
\text { systems }\end{array}$ & $\begin{array}{lr}\text { risks } & \text { when } \\
\text { introducing } & \text { new } \\
\text { electronic } & \text { control } \\
\text { systems } & \text { in } \\
\text { universities } & \end{array}$ & $\begin{array}{l}\text { introduction of } \\
\text { innovations in } \\
\text { IT-sphere of } \\
\text { higher education }\end{array}$ & $\begin{array}{l}\text { application of } \\
\text { information } \\
\text { technology in } \\
\text { teaching various } \\
\text { disciplines }\end{array}$ \\
\hline $\begin{array}{c}\text { Ramirez-Montoya M., } \\
\text { Garcia-Penalvo F. }\end{array}$ & 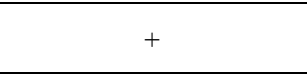 & + & & + & \\
\hline $\begin{array}{c}\text { Segura J., Quintero L., Mon } \\
\text { F. }\end{array}$ & & + & & & \\
\hline de Pablos Pons J. & & + & + & + & \\
\hline Wolfram L. & & + & + & & \\
\hline $\begin{array}{c}\text { Semenova T., Vilkova K., } \\
\text { Shcheglova I. }\end{array}$ & & + & & + & \\
\hline $\begin{array}{c}\text { Mohorovičić S., } \\
\text { Lasić-LazićJ., Strčić V. }\end{array}$ & & + & + & & \\
\hline $\begin{array}{c}\text { Izmalkova S., Romanchin V., } \\
\text { Zakirov A. }\end{array}$ & + & + & + & & \\
\hline David F., Abreu R. & & + & + & & \\
\hline Gushchin A. & + & + & + & & \\
\hline $\begin{array}{c}\text { Tlebaldiyeva M., Sadikov T., } \\
\text { Kamiyeva G., } \\
\text { Moldakhmetova Z. }\end{array}$ & & + & + & & \\
\hline Cornu B. & + & + & + & + & \\
\hline $\begin{array}{c}\text { Abdurahmanov Q., Tigay O., } \\
\text { Khamidov V. }\end{array}$ & + & + & & & \\
\hline $\begin{array}{c}\text { Kvon G., Vaks V., } \\
\text { Masalimova A., Kryukova } \\
\text { N., Rod Y., Shagieva R., } \\
\text { Khudzhatov M. }\end{array}$ & & + & & + & \\
\hline $\begin{array}{c}\text { Delgado-Almonte M., } \\
\text { Andreu H., Pedraja-Rejas L. }\end{array}$ & + & + & & & \\
\hline $\begin{array}{c}\text { El-Hefnawy M., } \\
\text { El-Bastawissy A., Kadry M. }\end{array}$ & + & + & & & \\
\hline Mlitwa N., Van Belle J. & & + & & + & \\
\hline Cui J., Wang Z. & & & & & + \\
\hline Naveh G. & & + & & + & \\
\hline Dong H., Li C., Zhang F. & & & & & + \\
\hline Pinho C., Franco M. & & + & & + & \\
\hline $\begin{array}{l}\text { Tulbassova B., Iskakova A., } \\
\text { Kuandykova J., } \\
\text { Nurgulzhanova A., } \\
\text { Kazangapova B., Ismagulova } \\
\text { Z, Askarova G. }\end{array}$ & & + & & + & \\
\hline $\begin{array}{l}\text { Kostadinova I, Getova I., } \\
\text { Dimitrov G., Nikolova B. }\end{array}$ & & + & + & + & \\
\hline Wang $X$ & & + & & & + \\
\hline Rodriguez S., Gonzalez M. & + & + & & + & \\
\hline Parsons D. & + & & & + & \\
\hline $\begin{array}{l}\text { Cadavieco J., Vazquez-Cano } \\
\text { E. }\end{array}$ & + & & & + & \\
\hline Hill C., Lawton W. & & & & + & \\
\hline Da Silva R., Spanhol F. & & + & & + & \\
\hline Froehlich D. & & + & & + & \\
\hline Rich E. & & & & & + \\
\hline $\begin{array}{l}\text { Leon-Urrutia M., Cobos R., } \\
\text { Dickens K. }\end{array}$ & & + & & + & \\
\hline Bastian J. & + & + & + & + & \\
\hline Wang F. & & + & & & + \\
\hline
\end{tabular}




\section{Results and Discussion}

The penetration of the Internet and the development of mobile technologies significantly change the modern economy, deeply penetrating into social life and work. If earlier the majority of work tasks were solved using a stationary computer, the young generation $\mathrm{Y}$ (born after 1980 ) and the younger generation $Z$ (born after 2000) cannot even imagine life without their smartphones. For modern youth, information search on the Internet and surfing the virtual world is routine. $99 \%$ of modern students have smartphones, $92 \%$ have their own computer, $84 \%$ download music from the Internet, $76 \%$ use instant messaging systems, $44 \%$ participate in social networks, $34 \%$ get all the news only through the Internet and almost do not watch TV (less than once a week), 28\% have their blogs, and $20 \%$ create their own web pages, $18 \%$ are online. Today, digitalization technology is changing very quickly. Moreover, the speed of their change increases all the time, and they, in turn, change everything else with which they interact. It is very important to understand this process and adapt to it appropriately. Rapidly changing IT brings society as a whole and education in particular, both new benefits and additional complications. In this regard, new approaches to education, greater use of IT facilities, greater involvement of students are needed [ Ramírez-Montoya, et al. 2017- Leon-Urrutia, et al. 2018].

In recent years, IT has changed very rapidly: cloud computing; large databases; social networks; natural interface; a variety of devices; constant communication with the network; artificial intelligence and machine learning; consumerization of IT.

The obtained results are a significant proof of the relevance of this research area. To cope with information flows any modern specialist should be able to receive, process and use information using computers, telecommunications and other IT facilities.

The analysis explicates the need to master modern digitalization technologies in the field of higher education, since they are one of the main components of the professional training of any teacher, including a specialist in the field of physical culture and sports. This requires the development and implementation in the educational process of higher education of professionally oriented program and program and pedagogical tools aimed at mastering the necessary knowledge, as well as accumulating personal experience in their use in pedagogical and sports activities.

\section{Discussion}

Professor Bernard Cornu, Director of Innovations CNED (France), in his work Technological and Pedagogical Problems of Higher Education and Digital Knowledge Society, described the innovations that are unavoidable in his opinion in pedagogy:
1. Mobile pedagogy: modernization of pedagogical tools and resources for mobile learning; new understanding of time; new formats of communication; new interactions; new attitude to the teacher.

2. Social pedagogy: individual / collective; networks, collective intelligence, teamwork; social networks; social pedagogy of the community

3. Pedagogy of time and space: the traditional class; "I study when I want and where I want"; the invention of new formats of time and space.

4. The transition from paper pedagogy to digital pedagogy: our (modern) pedagogy is firmly tied to paper; paper pedagogy cannot easily adapt to digital tools; the invention of digital pedagogy [ Cornu, 2011].

Another vector of the development of modern digitalization technologies, gaining popularity among the world's leading universities, is the so-called MOOCs-abbreviated from the English «Massive Open On-line Courses» [Mohorovičić, et al. 2011; Semenova, et al. 2018'; Cadavieco and Vazquez-Cano, 2017; Hill and Lawton, 2018].

The advantages of these projects are the expanded opportunities for individualized learning at any age. At the same time, many students state that it is more difficult to study within MOOCs than in an ordinary university: doing assignments requires a deep immersion in the subject, a lot of time is spent studying materials and working independently. The final exams are usually paid and accepted in regional testing centers or directly at home using special user identification devices. Until the end of the online course reaches no more than $10 \%$ of participants.

The largest consortium of Open Course Ware are free and open publications of high-quality university-level materials, including curricula, lectures, assignments, exam materials, organized as courses. The Open Course Ware includes institutes from 41 countries (for example: Massachusetts Institute of Technology in the Open Course Ware since 2001 has placed more than 2100 courses). The other largest resource, Open Learn, is 600 institutes from 22 countries, 57 million downloads, 8,000 hours of free learning resources.

In addition to MOOCs organized in accordance with the technology-based knowledge transfer formats, in recent years a new segment of online educational projects has been actively developing, aimed at training skills and abilities: from teaching reading to making difficult business decisions in situations of uncertainty. These are online training simulators that ensure the mastering of new algorithms of work due to the action and its subsequent reflection, in contrast to viewing video lectures and learning materials in the classical MOOCs. That is why the common feature of simulators is the game format of learning, which leads to action and is called gamification in the special literature (from the English word gamification). 
Every year, the demand for such complex computer simulators increases, so this segment of mass online courses, which ensure the technological formation of new competencies for millions of people around the world, strengthens its position in the global market of educational services.

Let's consider one more new concept Smart Education. Smart Education is a fundamentally new educational environment. This is a union of teachers, students and knowledge from around the world.

Smart is an object property that characterizes the integration in this object of two or more elements not previously connected, which is carried out using the Internet.

The term SMART comes from the English abbreviation:

$\mathrm{S}$-Self-Directed

M-Motivated

A-Adaptive

$\mathrm{R}$-Resource-enriched

T-Technology

Smart Education is self-directed, motivated, flexible, technological, based on self-directed, motivated, flexible, enriched with resources and technological methods of teaching. Accordingly: A Smart-teacher (student) is a participant in the educational process, constantly using technological innovations and the Internet to achieve a new quality of educational process that meets the requirements of Smart society.

In this regard, there is a new concept - a network student, which is characterized by: the flexibility in learning in an interactive environment; individualization of the program for each listener; multidisciplinary (interdisciplinary) training programs; the ability to learn at anytime and anywhere on the basis of free access to content around the world; an opportunity to work, which is most relevant for most modern students.

The theoretical analysis and generalization of the literature data on the problem of the development and introduction of innovative ITs in the educational process of universities confirms the existence of a problem situation [ Abdurahmanov, et al. 2010; Pussyrmanov, et al 2018].

By the beginning of the XXI century, scientists have begun to scientifically substantiate the use of modern information technologies in physical culture and sports [Cui \& Wang, 2014; Wang, 2013].

However, most modern specialists studying the application of ITs pay attention to the introduction of new electronic control systems in higher education [Kvon, et al. 2018; Tulbassova, et al. 2014].

Summarizing the above mentioned, we suppose that our research shows digitalization technologies in the field of physical culture and sports have not yet found a sufficiently wide application in higher education [Cui \& Wang, 2014; Dong \& Zhang, 2013; Rich, 2018; Wang, 2018]. Unfortunately, the majority of specialists in the field of physical culture and sports do not see the prospects of digitalization of physical education at the present stage. All this confirms the prospects of research in this direction.

\section{Conclusions}

Thus, it is necessary to emphasize the urgency of digitalization of the sphere of education, including physical culture education.

In our opinion, four main directions of using modern digitalization technologies in physical culture and sports can be distinguished:

1. In the educational process: to transmit theoretical knowledge and control them; as well as to monitor the physical preparedness, motor activity and psychophysical state of students in the process of physical training and sports.

2. In the process of sports training (programs: using biomechanical parameters to improve the effectiveness of training in motor activities, allowing to determine the parameters of physical activity, that is, medical and pedagogical control).

3. In the process of the competition: various video analysis programs allow online evaluation of the performance of the athlete (for example, the number and quality of technical and tactical actions of a specific player or team in the game); all sorts of computer systems start-finish, electronic systems of refereeing and timing, etc.

4. In health-improving physical culture: computer programs of health-improving orientation (for example, for evaluation of motor activity, for health training Personal trainer).

It is necessary to pay attention to the fact that changes today are no longer determined by computing technology, IT capabilities and software, but by the demands of modern youth and their willingness to change within the information society.

\section{Conflict of Interest}

The authors state that there is no conflict of interest.

\section{REFERENCES}

[1] Abdurahmanov, Q. P., Tigay, O. E., \& Khamidov, V. S. (2010). Complete implementation of information and communication technologies in educational process at universities example of physics. Paper presented at the 4th International Conference on Application of Information and Communication Technologies, AICT2010, doi:10.1109/IC AICT.2010.5612048.

[2] Adell Segura, J., Castañeda Quintero, L., \& Esteve Mon, F. 
(2018). Hacia la Ubersidad Conflictos y contradicciones de la universidad digital. RIED. Revista Iberoamericana de Educación a Distancia, 21(2), 51-68, doi:https://doi.org/10 $.5944 /$ ried.21.2.20669.

[3] Amiri Mikal, M., Pour Ramezan, E., Amar, T., \& Bigdeli, A. (2016). Spatial Analysis of Quality of Life in Economic Dimension of Villages of Lahijan Town. UCT Journal of Social Sciences and Humanities Research, 4(4), 21-28

[4] Bastian, J. (2017). Learning with Digital Media - Learning about Digital Media. An Inventory of Recent Emphases in Germany. DDS-DIE DEUTSCHE SCHULE, 109(2), 146-162.

[5] Cadavieco, J., \& Vazquez-Cano, E. (2017). Possibilities of using geolocation and augmented reality in education. EDUCACION XX1, 20(2), 319-342. DOI: 10.5944/educX $\mathrm{X} 1.10852$.

[6] Cornu, B. (2011). Technological and Pedagogical challenges for Higher Education in a Knowledge Digital Society. International Conference EICTHE-2011. Emerging ICTs in Higher Education. July 8-10, 2011 Ulaanbaatar, Mongolia. Available from https://iite.unesco.org/files/news/387945/5 9113842-Second-Announcement.pdf.

[7] Cui, J. G., \& Wang, Z. S. (2014). The application of information technology in sports teaching in private universities. Advanced Materials Research, 998-999, 1717-1720. doi: 10.4028/www.scientific.net/AMR.998-99 9.1717.

[8] Cuevas, O., Larios, V., Peralta, J. X., \& Jiménez, A. R. (2018). Mathematical Knowledge of Students who Aspire to Enroll in Engineering Programs. International Electronic Journal of Mathematics Education, 13(3), 161-169. https://doi.org/10.12973/iejme/3832

[9] Da Silva, R., \& Spanhol, F. (2018). Use of Artificial Intelligence in the Structuring of Hybrid Learning Environments. Revista educaonline, 12(3), 45-68.

[10] David, F., \& Abreu, R. (2014). Information technology in education: Recent developments in higher education. Paper presented at the Iberian Conference on Information Systems and Technologies, CISTI, doi:10.1109/CISTI.2014.687695 0

[11] De Pablos Pons, J. (2018). Las tecnologías digitales y su impacto en la Universidad. Las nuevas mediaciones. RIED. Revista Iberoamericana de Educación a Distancia, 21(2), 83-95. doi: https://doi.org/10.5944/ried.21.2.20733.

[12] Delgado-Almonte, M., Andreu, H. B., \& Pedraja-Rejas, L. (2010). Information technologies in higher education: Lessons learned in industrial engineering. Educational Technology and Society, 13(4), 140-154.

[13] Dong, H. -J., Li, C. -F., \& Zhang, F. -Y. (2013). Research on information technology in sport educational training systemu Proceedings of the 2nd International Conference on Green Communications and Networks 2012 (GCN 2012), 5, 227. doi:10.1007/978-3-642-35398-7_51.

[14] El-Hefnawy, M. R. M., El-Bastawissy, A. H., \& Kadry, M. A. (2014). Towards a composite index for measuring the higher education institutions in Egypt. Paper presented at the Proceedings of 2014 Science and Information Conference, SAI 2014, 31-41. doi: 10.1109/SAI.2014.6918
169.

[15] Ebrahim Abadi, M., \& Namdar, Sh. (2016). Comparison between the legal nature of commercial factoring and similar legal institutions. UCT Journal of Social Sciences and Humanities Research, 4(2), 10-15.

[16] Gushchin, A. V. (2015). System model the development of information and technological support of higher pedagogical education. Sovremennye problem nauki i obrazovaniia, 5. Available from http://science-education.ru $/ \mathrm{ru} /$ article/view? id=21695 (in Russian)

[17] Hill, C., \& Lawton, W. (2018). Universities, the digital divide and global inequality. Journal of higher education policy and management, 40(6) Special Issue: SI, 598-610.

[18] Izmalkova, S. A., Romanchin, V. I., \& Zakirov, A. I. (2014). Methods and technologies development of the Russian education system on the basis of large-scale innovation. Izvestiya Tul'skogo gosudarstvennogo universiteta, 5-1. Available from http://cyberleninka.ru/article/n/metody-i-tehnologii-razviti ya-rossiyskoy-sistemy-obrazovaniya-na-osnove-masshtabn yh-innovatsiy.pdf (in Russian).

[19] Kostadinova, I., Getova, I., Dimitrov, G., \& Nikolova, B. (2017). Model for building competencies through an electronic system for assessment of knowledge. 10th Annual International Conference of Education, Research and Innovation (ICERI), Proceedings, 430-436.

[20] Kvon, G. M., Vaks, V. B., Masalimova, A. R., Kryukova, N. I., Rod, Y. S., Shagieva, R. V., \& Khudzhatov, M. B. (2018). Risk in implementing new electronic management systems at universities. Eurasia Journal of Mathematics, Science and Technology Education, 14(3), 891-902. doi:10.12973/ejms te/81060.

[21] Leon-Urrutia, M., Cobos, R., Dickens, K., (2018). MOOCs and their Influence on Higher Education Institutions: Perspectives from the Insiders. Journal of new approaches in educational research, 7(1), 40-45.

[22] Mlitwa, N., \& Van Belle, J. -P. (2011). Mediators for lecturer perspectives on learning management systems at universities in the Western cape, South Africa. Paper presented at the PACIS 2011 - 15th Pacific Asia Conference on Information Systems: Quality Research in Pacific.

[23] Mohorovičić, S., Lasić-Lazić, J., \& Strčić, V. (2011). Webinars in higher education. Paper presented at the MIPRO 2011 - 34th International Convention on Information and Communication Technology, Electronics and Microelectronics - Proceedings, 1271-1274.

[24] Naveh, G. (2015). Information technology in higher education teaching: Much ado about nothing? Paper presented at the CSEDU 2015 - 7th International Conference on Computer Supported Education, Proceedings, 2, 450-454.

[25] Parsons, D. (2017). Mobile Learning Policy Formulation and Enactment in New Zealand. Mobile learning in higher education in the asia-pacific region: harnessing trends and challenging orthodoxies, 40, 423-441. DOI: 10.1007/978-9 81-10-4944-6 21.

[26] Pussyrmanov, N., Rystina, I., Bulegenova, B., Askeyeva, G., \& Gabdulina, B. (2018). President Nursultan Nazarbayevs 
program article "The course towards future: Modernization of public consciousness"-ideology, value and political aspects. Opción, 34(85-2), 824-837.

[27] Parsons, D. (2017). The future of mobile learning and implications for education and training. Transforming education in the gulf region: emerging learning technologies and innovative pedagogy for the 21 st century, 224-236.

[28] Pinho, C., \& Franco, M. (2017). The role of the CIO in strategy for innovative information technology in higher education institutions. Higher Education Policy, 30(3), 361-380. doi: 10.1057/s41307-016-0028-2.

[29] Ramírez-Montoya, M., \& García-Peñalvo, F. (2017). Effective integration of the mobile device into Education and learning. Revista Iberoamericana de Educación a Distancia, 20(2), 29-47.

[30] Rich, E. (2018). Gender, health and physical activity in the digital age: between postfeminism and pedagogical possibilities. SPORT EDUCATION AND SOCIETY, 23(8), 736-747. DOI: 10.1080/13573322.2018.1497593.

[31] Semenova, T., Vilkova, K., \& Shcheglova, I. (2018). The MOOC Market: Prospects for Russia. Voprosy obrazovaniya / Educational Studies Moscow, 2, 173-197.

[32] Tlebaldiyeva, M., Sadikov, T., Kamiyeva, G., \& Moldakhmetova, Z. (2016). The implementation of information technologies in higher education: A case of Kazakhstan and Turkey. Journal of Theoretical and Applied Information Technology, 88(3), 517-524.

[33] Tulbassova, B. K., Iskakova, A. K., Kuandykova, J. R., Nurgulzhanova, A. N., Kazangapova, B. A., Ismagulova, Z. S., \& Askarova, G. A. (2014). Information technologies in higher education of the republic of Kazakhstan. Life Science Journal, 11(SPEC. ISSUE 7), 322-326.

[34] Wang, F. -Y. (2013). Research of CAS in physical training. Lecture Notes in Electrical Engineering 206 LNEE, 457-463. doi:10.1007/978-1-4471-4790-9 59.

[35] Wang, X. (2018). The Application of Multimedia and Network Technology on College Physical Education. Advances in Social Science, Education and Humanities Research, 4th International Conference on Education Technology, Management and Humanities Science, 194.

[36] Wolfram, L. (2018). Economic Implications and Stakeholder Reactions in a Digital University Environment. RED. Revista de Educación a Distancia. 57(3). DOI: http://dx.doi.org/10.6018/red/57/3 http://www.um.es/ead/r ed/57/laaser.pdf. 